\title{
Herminio Barreiro Rodríguez. Escolma fotobiográfica dos anos en Compostela (1976-2010)
}

\author{
Antón COSTA RICO \\ Vicente PEÑA SAAVEDRA \\ Universidade de Santiago de Compostela
}
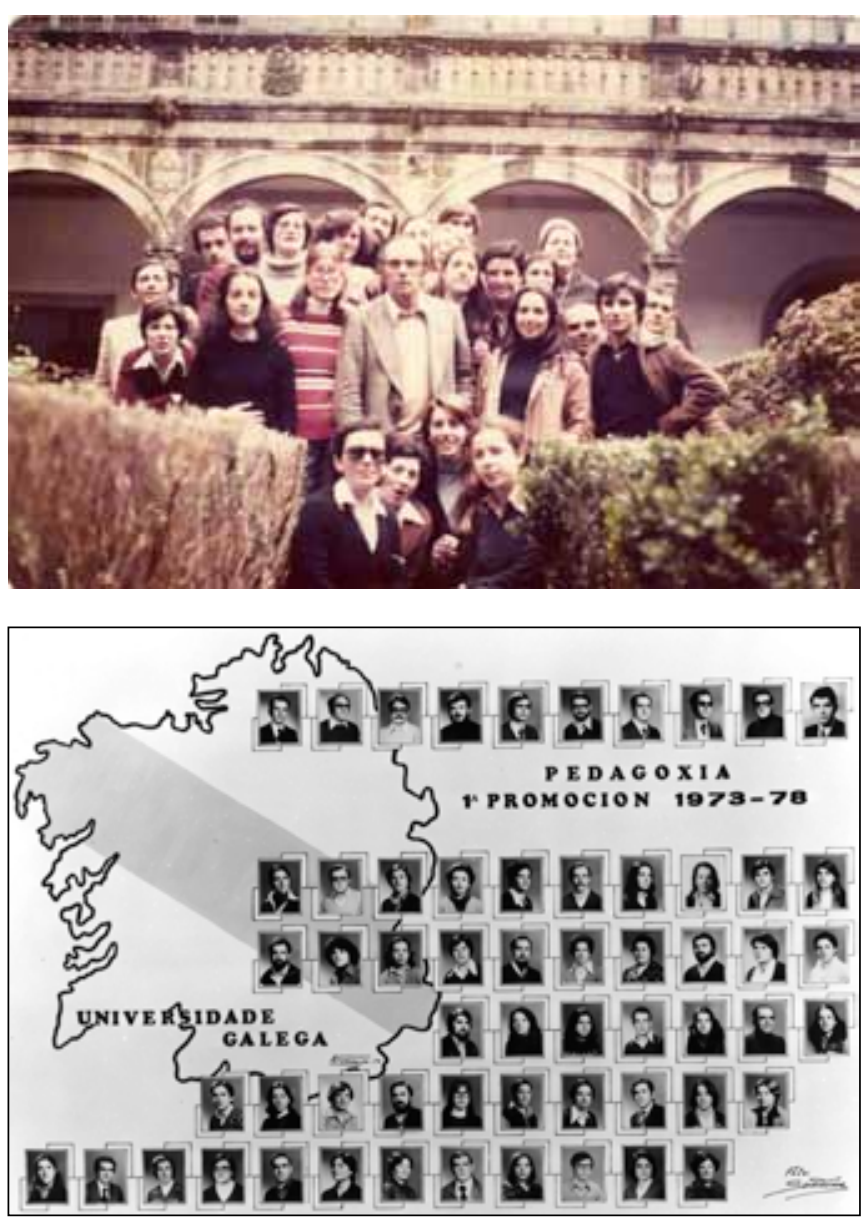

1978. No xardín de Fonseca. Alí estaba o profesor na compaña dun bo fato de alumnos e alumnas. Nun espazo acugulado de historia aprendendo das inquedanzas dos educadores $e$ educadoras doutrora, que deixaran memoria fértil para o presente,... e para o futuro dos que pronto irían comezar a exercer como dignos profesionais no mundo da educación.

1978. Orla auroral. A primeira andaina de titulados universitarios en Pedagoxía na historia de Galicia. Naqueles anos, un pouco adiante e un pouco atrás, era a primeira vez para moitas cousas da historia contemporánea da Nación, e Herminio alí estaba, un chisco senior á beira de colegas máis novos. O tempo pasa. Daqueles dez profesores, todos varóns, xa só catro continúan como docentes en activo e a pé de obra nas aulas de Compostela. Entre o alumnado, homes e mulleres, hai arestora un considerable fato de profesionais recoñecidos. 
1983. Jules Ferry. Jules Ferry, se cadra sería daquela case un "ninguén" para Narciso e para Antón, que acompañaban a Herminio na foto nas Tullerías de París, de non ser pola información e os coñecementos do noso "profesor". Ferry, o grande impulsor da escola primaria republicana, cívica (no mellor espírito da época) e laica nos anos oitenta do século XIX. Unha longa viaxe de carro para chegar a París cunha grande caixa de libros de Galicia para o Centro Galego.
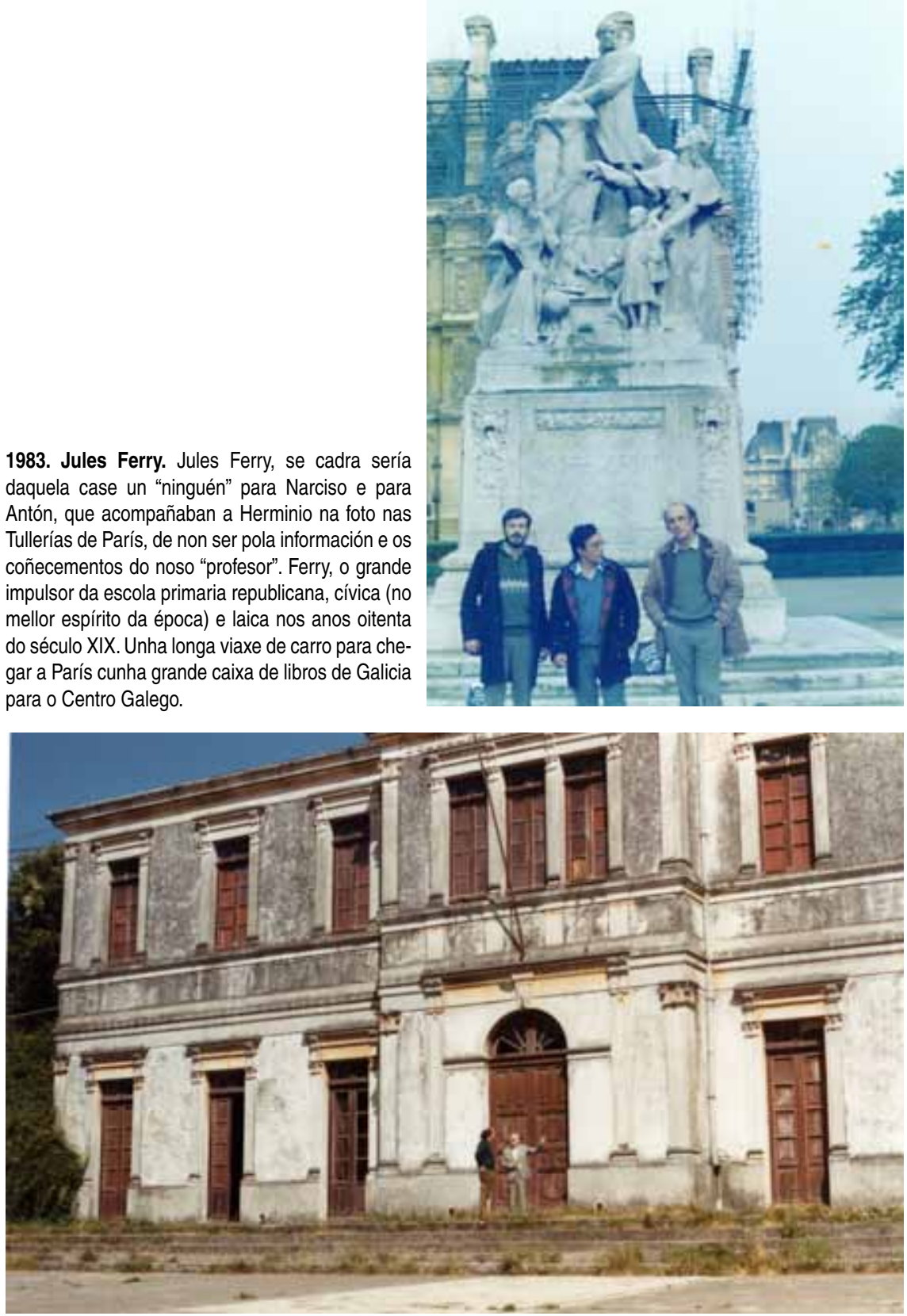

1985. No patio das escolas dos irmáns García Naveira. Con José Dapena Espiñeira, derradeiro mestre do padroado das escolas "García Hermanos", en Betanzos, xuño de 1985. Despois dunha viaxe de investigación polas terras de Bezoucos, onde visitou, canda a Vicente Peña, ao erudito local Antonio Felpeto García, mestre da parroquia de Cervás. 


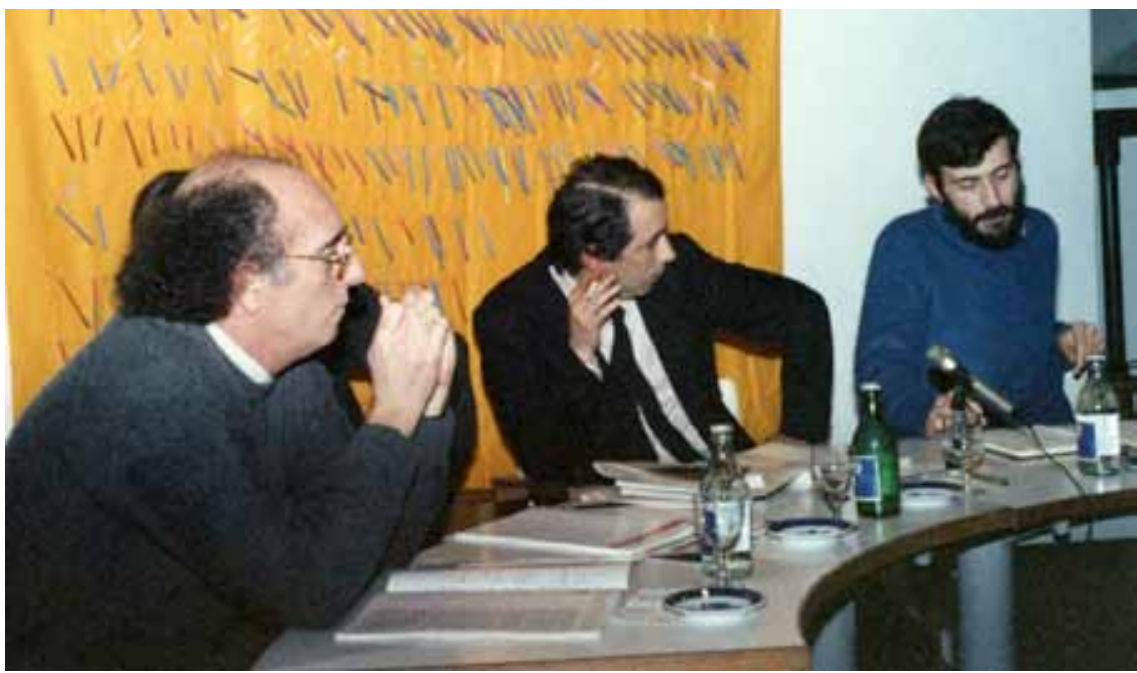

1986. A Revista Galega de Educación. Na primavera de 1986 outra iniciativa botaba a andar: era a Revista Galega de Educación promovida por Nova Escola Galega, coa colaboración editorial de Edicións Xerais de Galicia. Como noutras ocasións, houbo presentación na Galería Sargadelos de Compostela. E na foto están Luís Mariño, 0 editor de Xerais, xa hai anos dabondo falecido, Herminio Barreiro e Antón Costa, os tres, con outros, tantas veces presentes naquel ateneo sargadeliano dos anos oitenta.

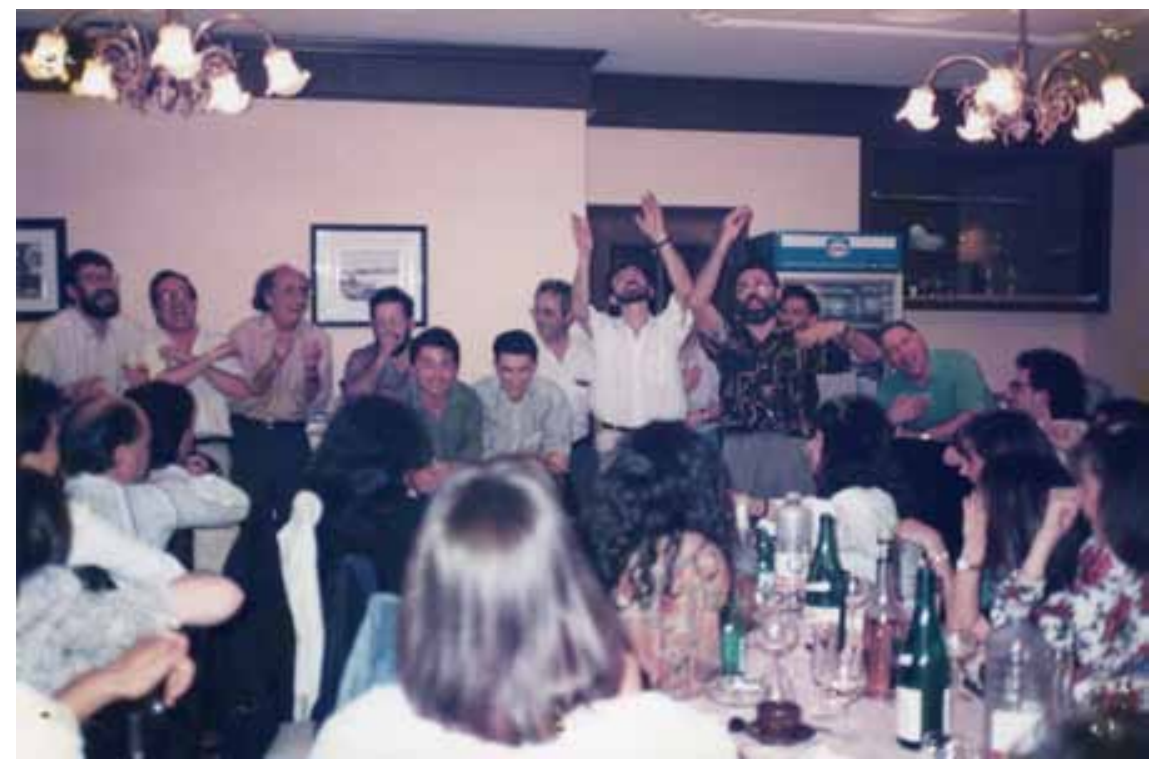

1986 circa. De festa. 0 estilo dos docentes da Sección de Pedagoxía tivo dende o comezo como marca a proximidade ao alumnado. E nisto Herminio Barreiro ía por diante, dando confianza á nova mocidade. Dende as aulas, os corredores, o bar,... e tamén deixándose invitar por eles para ir a unha festa. $E$ aí temos, señor, un mangado de profesores un pouco titiriteiros por unha noite. Pódese ollar que cada un vai cunha melodía. ¿Falla de ensaio, espontaneidade ou comedia? 

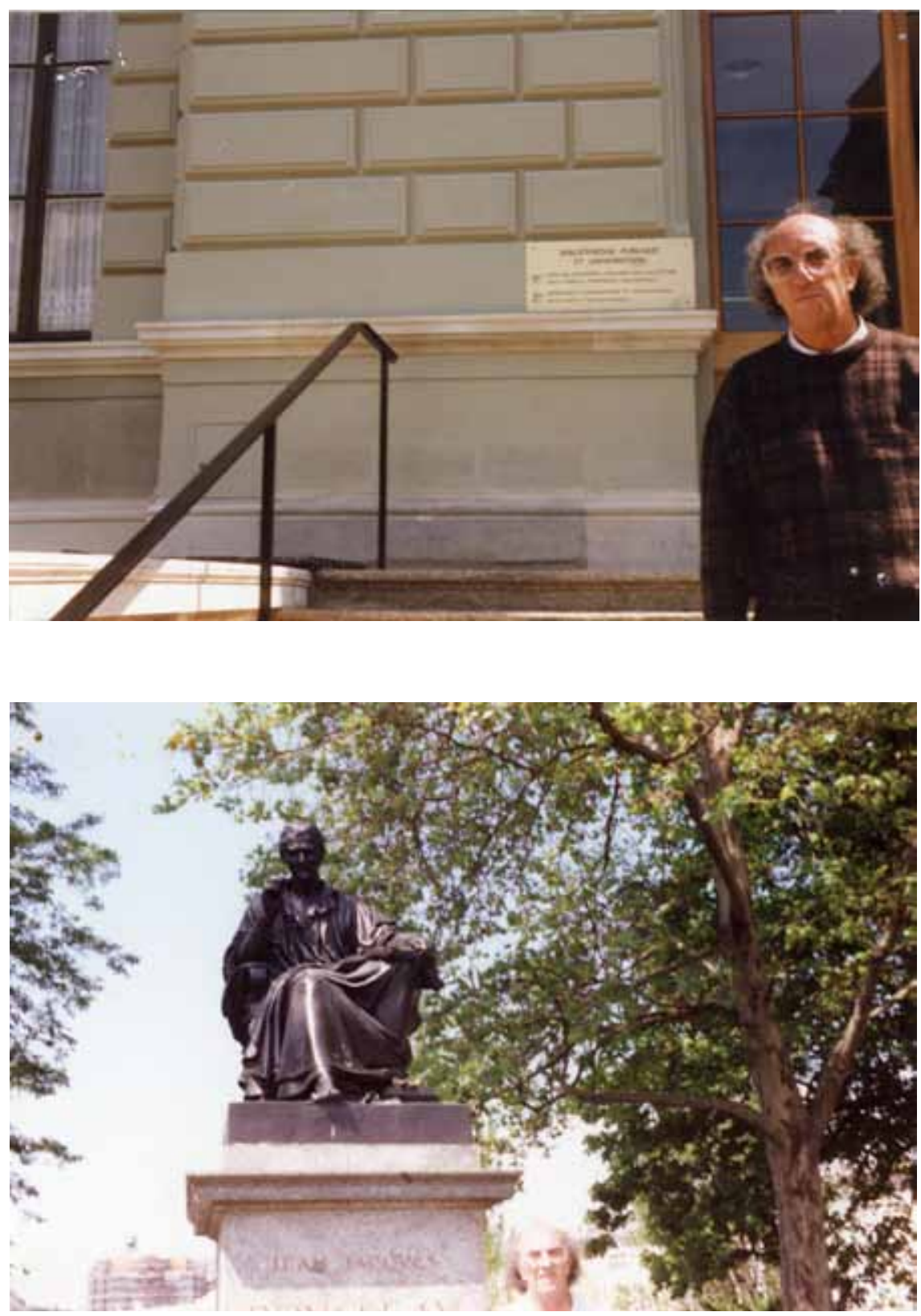

1990. Xenebra. Herminio Barreiro consagroulle moitas horas de estudo e lectura aos textos de Jean Jacques Rousseau e tamén valiosas páxinas escritas con xorne hermenéutico. Sendo así, no camiño investigador impoñíase unha visita a algún dos escenarios do ilustrado; por exemplo, a Xenebra, como quedou reflectido en dúas fotos: unha saíndo da Biblioteca Universitaria da cidade e outra nese lugar, un pequeniño illó, que abre a porta ao Lac Leman e que coñecemos como l'île de Rousseau. 


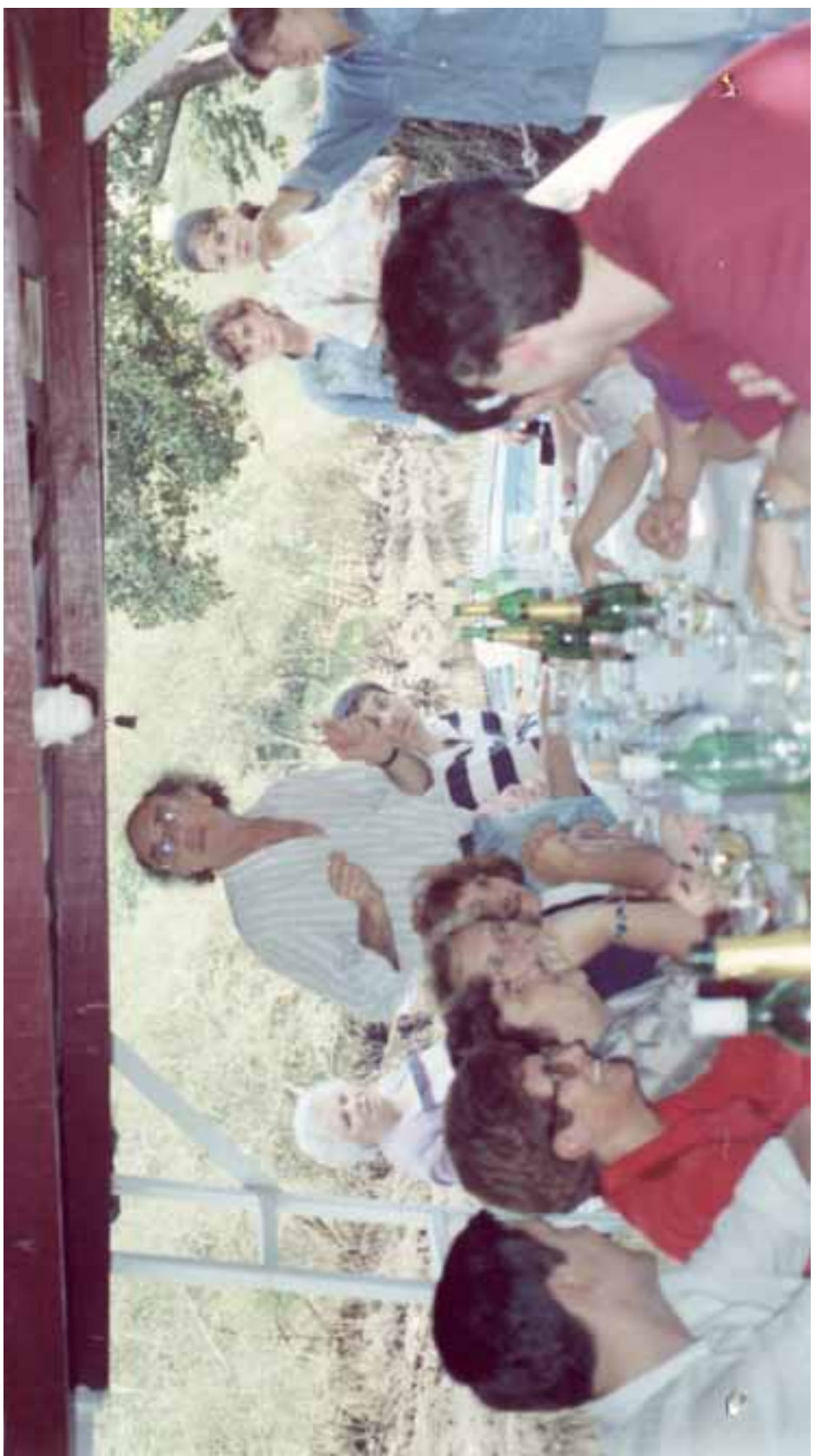

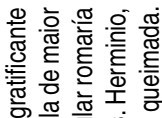

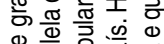

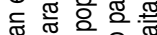

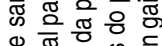

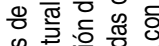
渮 동 융 융 원 등 竞 ब1

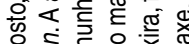
응 언 Ф) 옹 정

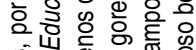
ต이 ๘

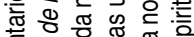

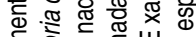

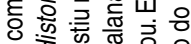

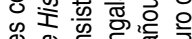

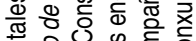
ш 옹웡ㅇㅇㅇㅇㅇ 힝응 흥 흐 응 웅 잉 응 을 휸 (1) ญ ํ

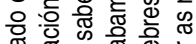
薷

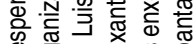
잉 응 호 혼융

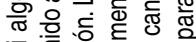
은 특 웡 웅 응

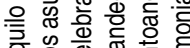

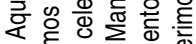

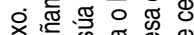
증 亭

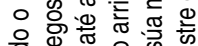
든 힝 응 은 종 토

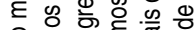

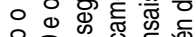

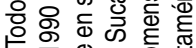
ต் Ф ळ

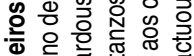

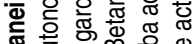
ऽั

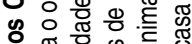

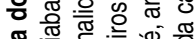

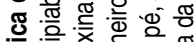
흥.등 응 등 힌

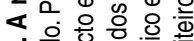

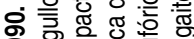
응ㅎㅎ으르응 


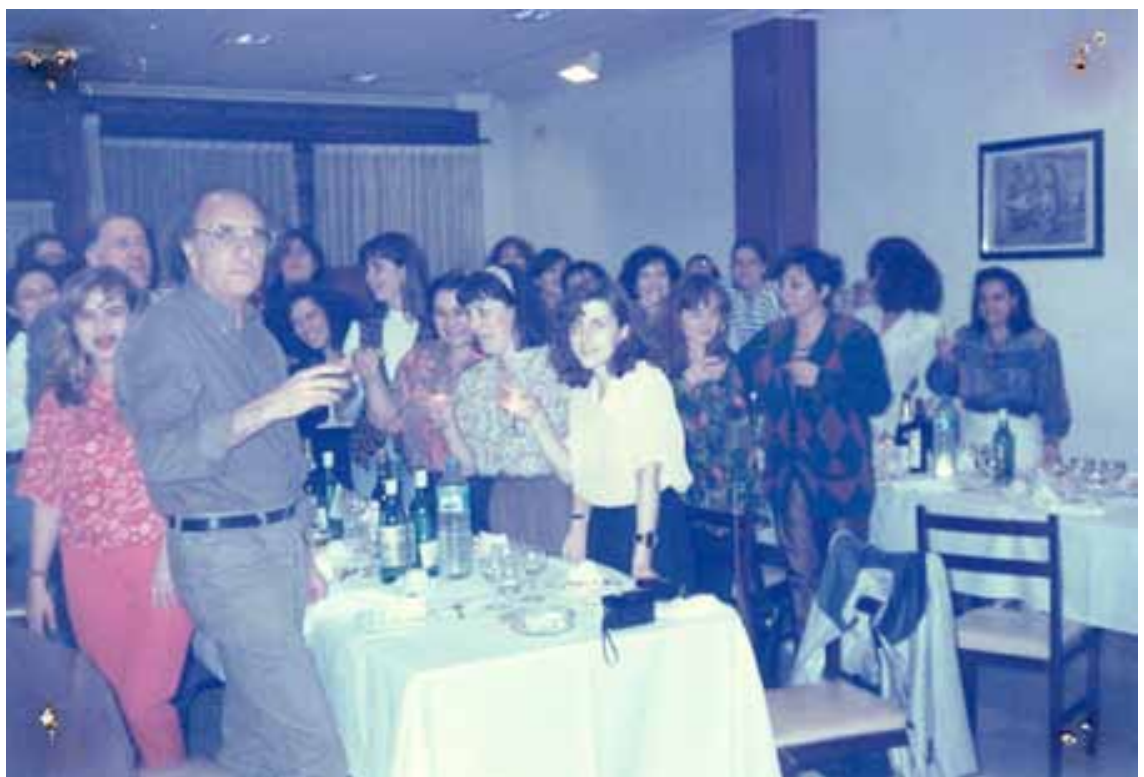

1992. Brindando polo futuro. As alumnas e os alumnos de Pedagoxía gustaban de contar co profesorado na cea de fin de carreira. Sentir que os profes entraban un chisco no xogo das confianzas, para narrar algún díxome díxome non maledicente, ou para contar un sucedido choqueiro, dos que acontecen con algunha miudeza na vida das aulas e ao longo dun ciclo. E con esa proximidade andabamos, e andaba o Herminio ano tras ano, case sen falta, porque se notaría.

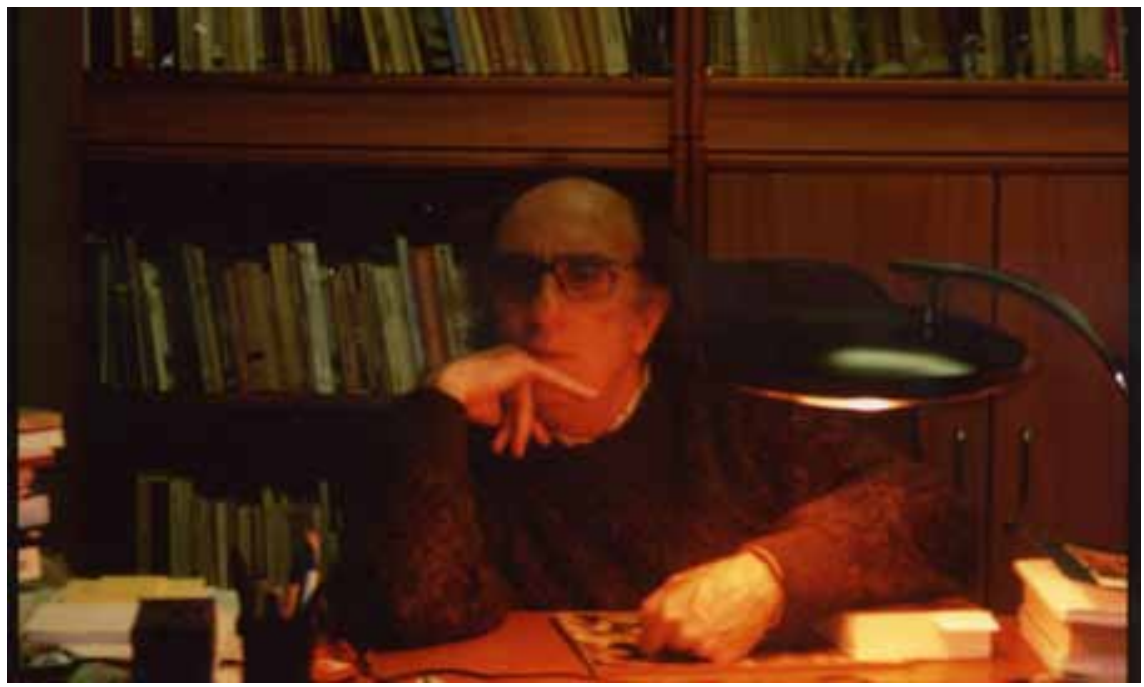

Entre décadas. Probablemente no tránsito dos anos 80 aos 90. En plena invernía. Co flexo aceso no seu despacho do Campus Sur. A mesa sempre ateigada de libros diversos. As páxinas sinaladas con papeis que el coidadosamente cortaba para lle serviren de marcas de lectura. E un vello exemplar da revista cubana Bohemia como cartafol de confianza e complicidade para a escrita. Arreo parolando e asentando con firmeza e paixón argumentos e conviccións. 


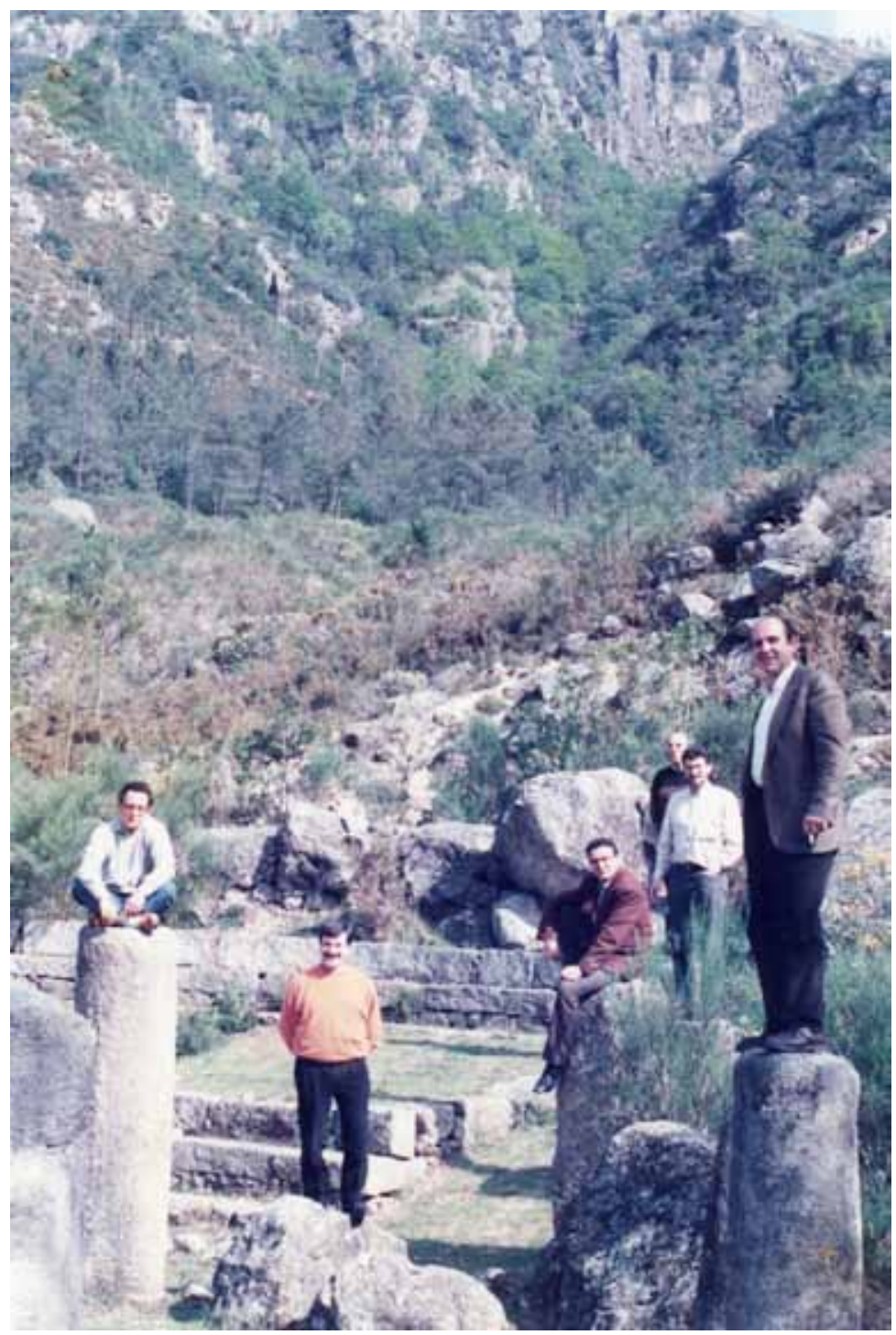

1992. Polo Camiño da Xeira. Sobre os miliarios que pespontean a calzada romana "Vía Nova", enlace entre a Bracara Augusta (Braga) e a Astúrica Augusta (Astorga), na serra pedregosa do singular enclave de Portela do Home, en plena raia seca do Parque Natural do Xurés-Gerês, vínculo transfronteirizo e patrimonio de dúas terras irmás. Non se trata dos profesores dunha orquestra ou dos compoñentes dun conxunto musical de moda, senón dun grupo de humildes docentes universitarios (Narciso, Anxo, Xosé Manuel, Herminio, Vicente e Uxío), daquela aínda novos, case de estrea no peregrinar internacionalista, en dirección a San Pedro do Sul, fermosa localidade balnearia de Portugal, onde canda outros colegas dos dous países veciños tomarían parte no I Encontro Ibérico de História da Educação, entre 024 e 026 de abril. Como curiosidade cómpre subliñar que a representación galega no evento, ao cabo, resultou ser a máis cuantiosa de España. Algunha razón habería... e tamén algún responsable (¿sería o que fixo a foto e non aparece nela? As ausencias polo regular delatan). 


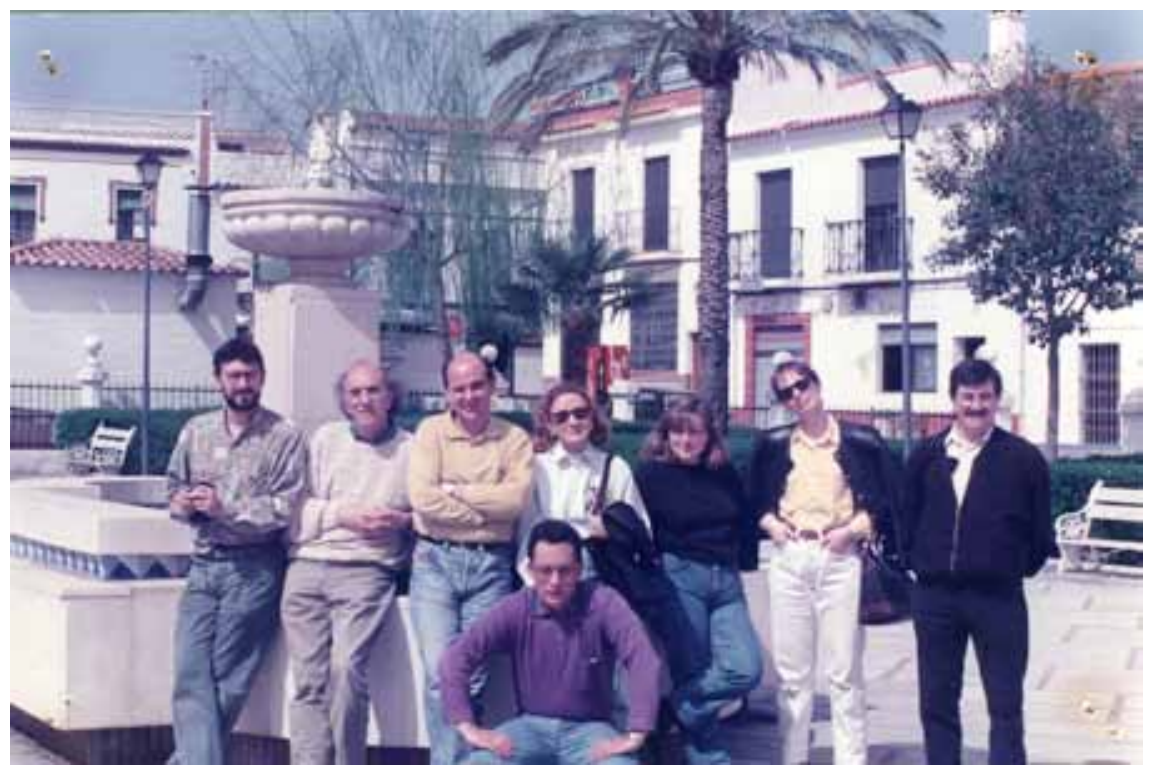

1993. Parada e folgos por terras de Andalucía. Santa Olalla (Huelva), o 21 ou 022 de marzo de 1993, camiño de Torremolinos (Málaga), onde participamos no VII Coloquio Nacional de Historia de la Educación. Arrimados á fonte seca, cansos da longa viaxe á que nunca nos afaciamos e abraiados pola calor dun sol de xustiza, quixemos que aquel intre perdurara na memoria do tempo. E se cadra até o conseguimos. Agachado fica Narciso, e de pé: Vicente, Herminio, Uxío, Carmen, Sabela, Mํㅡㄹ Carmen e Anxo Serafín..., e, canda eles todos, o fotógrafo fóra de plano por non apurar o paso.

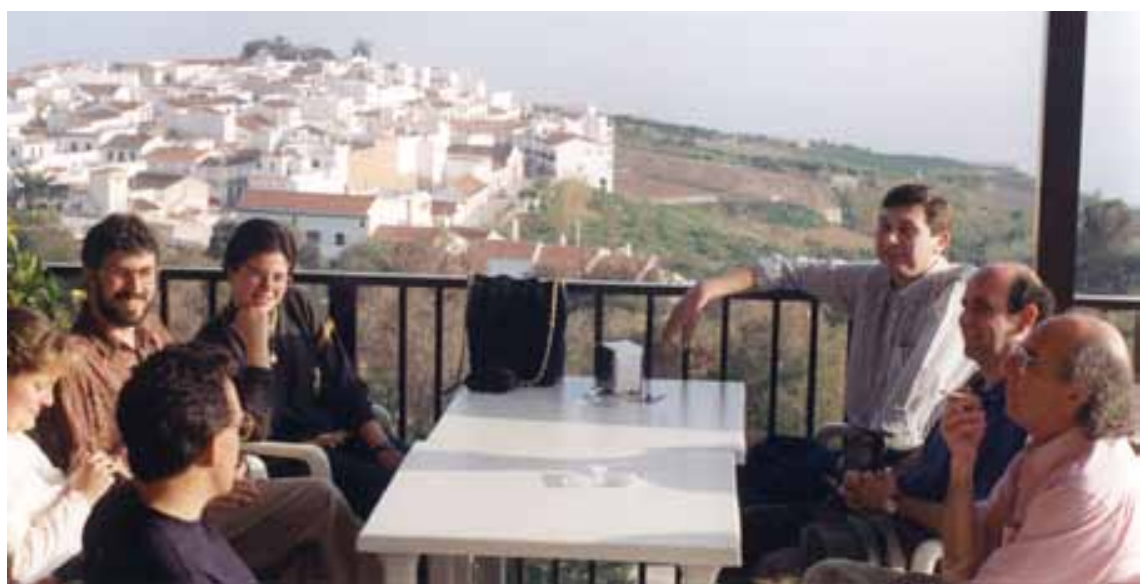

1993. En Nerja (Málaga). De faladoiro nunha terraza, coa colmea inmobiliaria, impoluta e compacta, de Nerja ao fondo. Herminio termaba entre os dedos do infalible Ducados, que degustaba calmo nas horas de vagar con gozo e estilo, coma regalía de culto dun profano e recorrente ritual. A carón del Uxío, Luis, Loli, Vicente, Sabela e Narciso. Ocorría nunha tarde de acougo e turismo co gallo do VII Coloquio Nacional de Historia de la Educación, celebrado en Torremolinos do 23 ao 26 de marzo de 1993. O tema examinado foi: Educación y Europeísmo. De Vives a Comenio. Herminio presentou unha comunicación titulada: "Ignacio de Loyola, entre Vives y Comenio (notas marginales desde una visión generalista del siglo XVI)". 

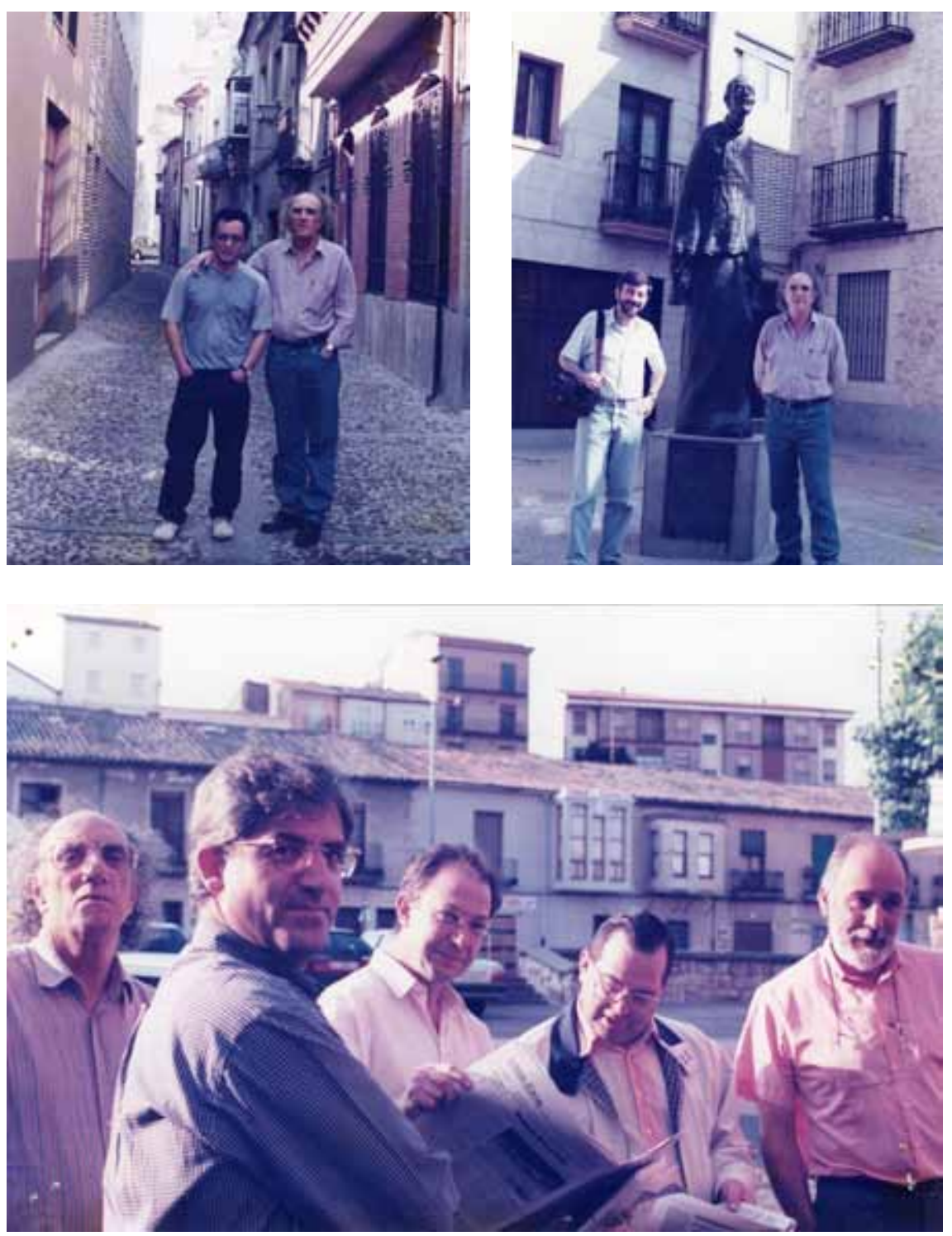

1995. Encontro Ibérico. A través do profesor lisboeta Antonio Nóvoa e do da Complutense Julio Ruiz Berrio concretárase no comezo dos noventa o Primeiro Encontro lbérico (Portugal-España) de Historia da Educaçâo en Sâo Pedro do Sul, e no noventaecinco tocoulle a sede a Zamora. No 2001 organizariamos o Grupo Galego o V Encontro en Allaríz, tamén de feliz recordaçâo. 0 de Zamora serviu, ademais, para coñecer a histórica cidade de Toro e de alí proceden estas fotos de Herminio con Narciso e con Antón. En Zamora foi feita a foto de grupo en que Herminio aparece con outros colegas: Ruiz Berrio, de Madrid; Josep G. Agapito, de Barcelona; Fernández Soria, de Valencia, e Salomó Marqués, de Girona. 


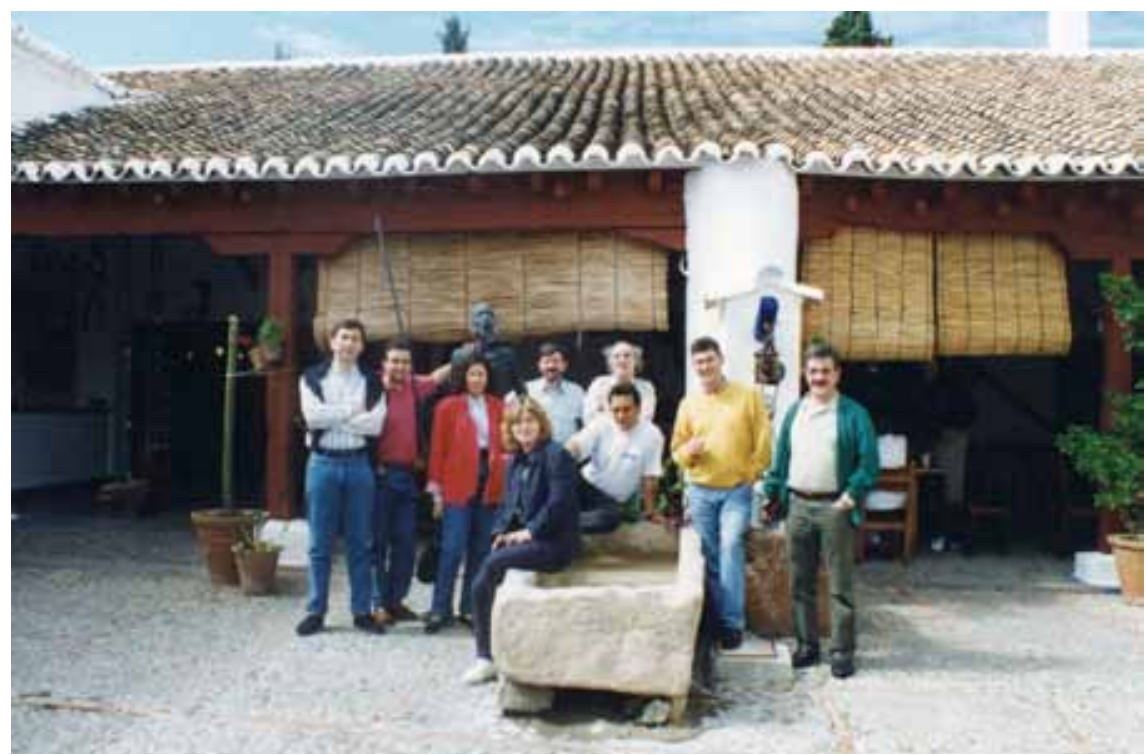

1996. En un lugar de la Mancha... Así comeza sempre Don Quixote. En 1996 o equipo ou grupo dos historiadores e historiadoras da educación de Galicia baixaba camiño do Coloquio de Historia de la Educación de Granada e a Venta del Quijote en Puerto Lápice, de singular resonancia para Herminio (sen saberes nós o porque) era un agradable lugar para tomar un café, e botar mentes de Sancho, o realista, e dos avatares de Quixote, ao tempo de nos repartir os papeis; a ver quen se parecía máis a Sancho e quen a Quixote, cousa non doada de establecer, pois o mundo mesturouse moito nos tempos que nos precederon.

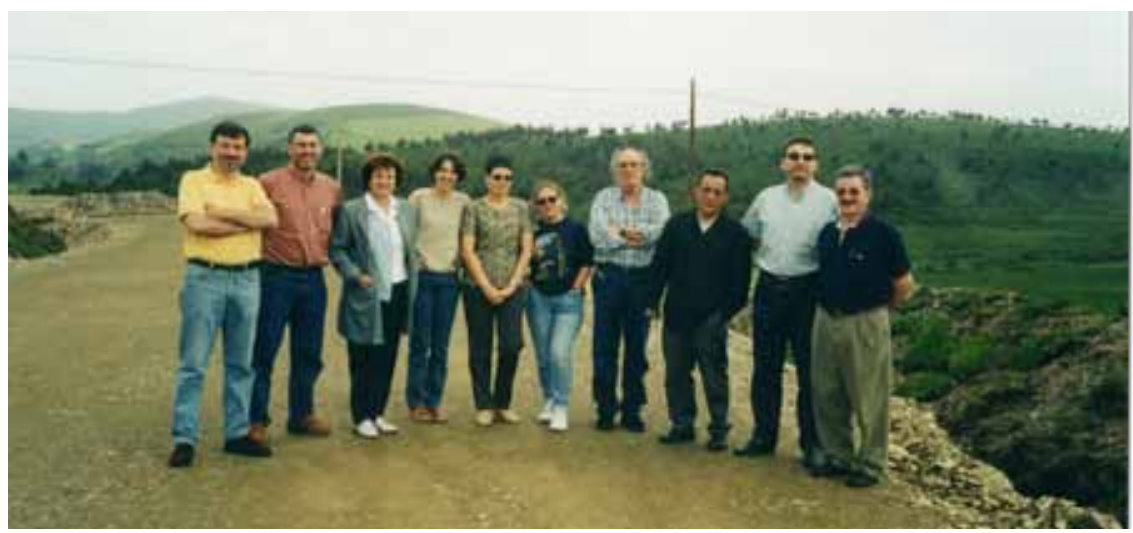

2001. Preto do ceo. Nos altos cumes de A Fonsagrada, en dirección a Taramundi, cos perfís delongados e romos da montaña como decorado natural de fondo. Tamén a esta paisaxe lle acaían os versos de Uxío Novoneyra cando dende Os eidos con forza e emoción proclamaba: "Eiquí síntese ben o pouco que é un home". Corría a primavera de 2001 cando, como en tantas outras ocasións, emprendemos viaxe xuntos, desta volta para tomar parte no XI Coloquio Nacional de Historia de la Educación, que se realizou en Oviedo, entre 012 e 015 de xuño. Herminio Barreiro defendeu unha contribución que titulou: "Pedagogía, educación social, educación popular, educación pública... (breves consideraciones sobre algunos programas docentes)". Na fotografía, de esquerda a dereita: Antón, Vicente, Aida, Ana, Loli, Sabela, Herminio, Narciso, Luis e Anxo Serafín. 


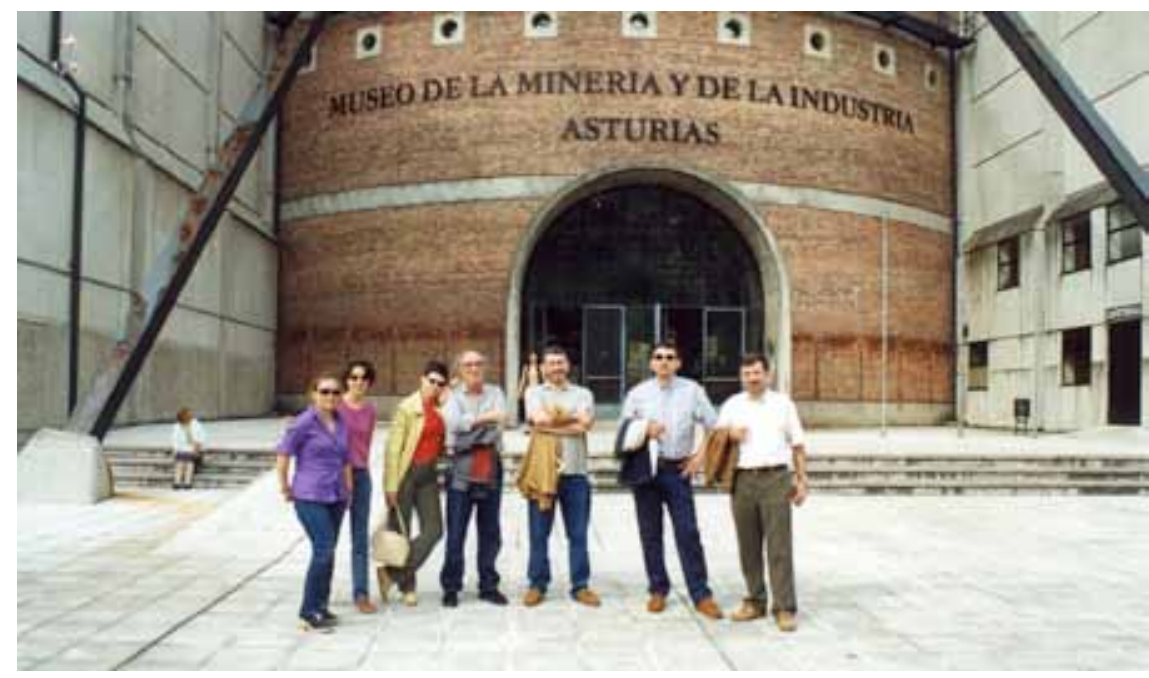

2001. Museo da Minería. Non hai Coloquio de Historia de la Educación -un espazo de debate de numerosas comunicacións académicas, e de escoita dalgunha magna conferencia- sen os tempos de convivencia e de visita. No Coloquio de Oviedo fomos ao impoñente cabo Peñas, e "apalpamos" a friaxe das minas; xa fóra saiamos do susto, arrodeando ao Herminio como tiñamos por costume.

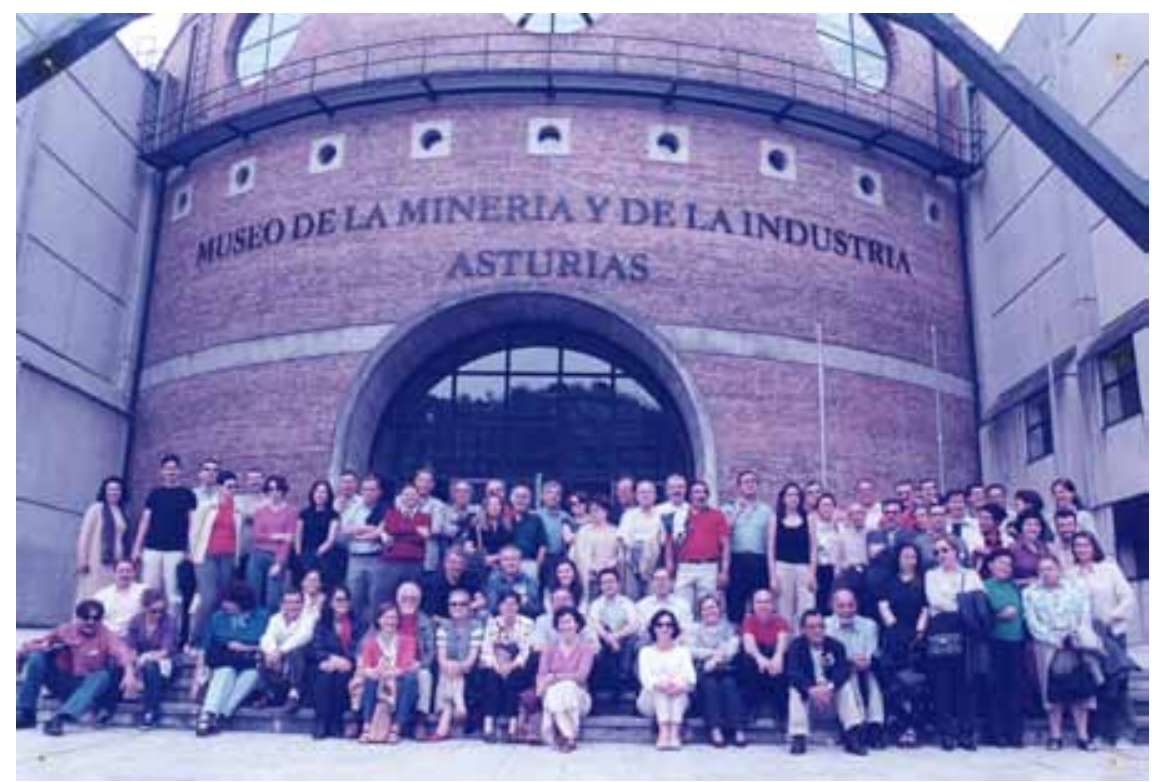

2001. Familia extensa. A foto, que vai alén do grupo galego, ten 0 interese de poder ollar 0 conxunto dos asistentes ao XI Coloquio Nacional de Historia de la Educación. Entre ese xentío, profesores, profesoras, bolseiras, investigadores,... relacionados por unha vía ou por outra coa historia da educación en España, estaban as galegas e os galegos, e alí tamén o Herminio. 


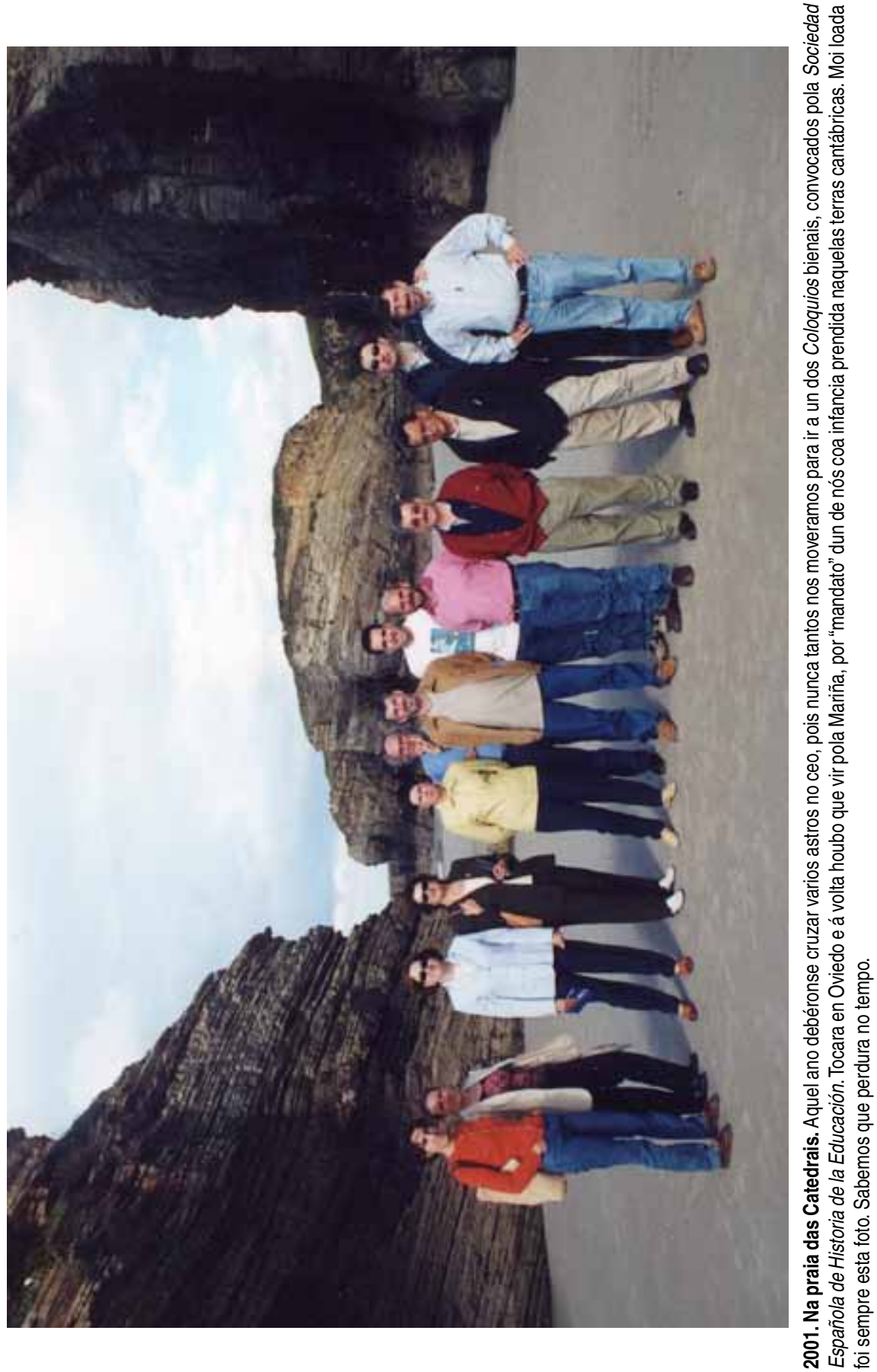




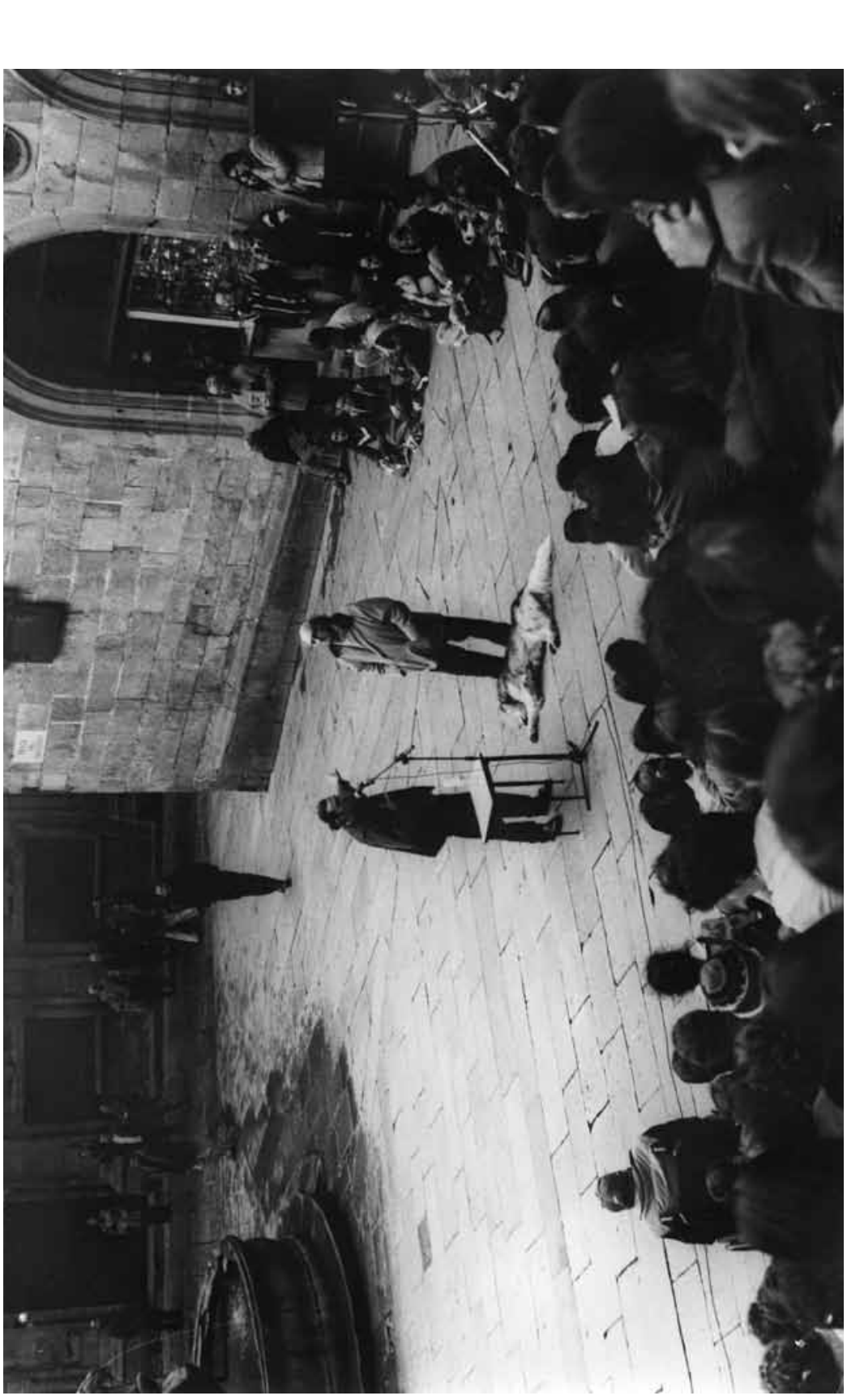

为完这

딩 है

E्ष

造空

ㄷㅀ 응 중

홍응 응

क्षे

空

屯 ㅎㅇㅇㅎㅇ

\% 䟢

(

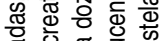

둔

해원

o हो 00

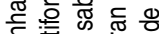

可 듄

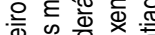

密: 응 응

은 일 용

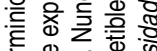
由 工 능 듕 뒁 के फ

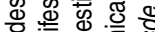
ช 뜨워 등 遂 必 ᄃ

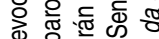

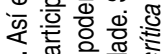
은 융 응 힌든

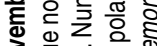
궁

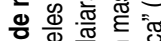
웡 웡ㅎㅇ

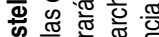

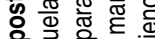
을 긍 웡 잉ㅎㅀ

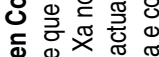
ฮ $\times$ 응 융 웧원

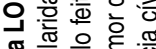
젱응 퉁 $\frac{\pi}{0}$

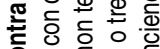

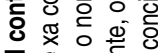

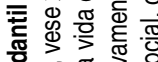

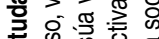
声 훙 을 융

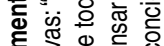

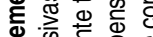

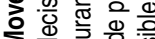
$2 \%$ 항

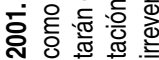




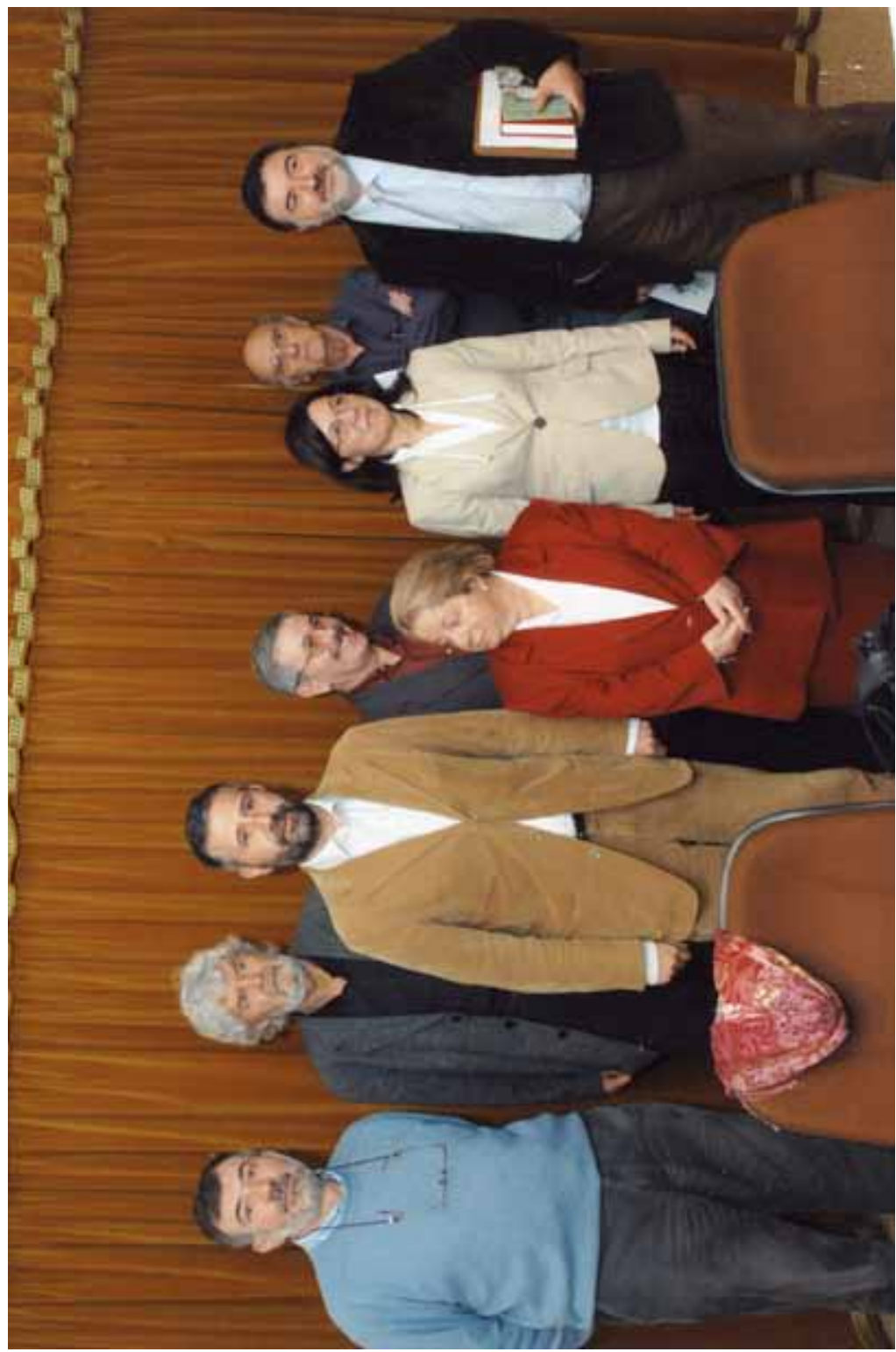

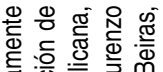
중 융 要 造 尊 응 还 . :은. (0)

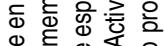

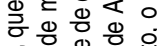

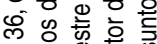

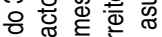

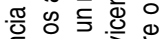
它 응 융 중 为 㢲 홍 ᄚ

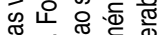
융

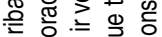

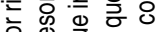
은 흥용 흔

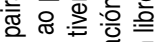
ه

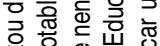
증 응 \% 응 웜 긍 웡 迹 政

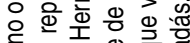
훙ㅇㅇㅇㅎㅁ

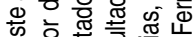
递覀

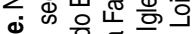

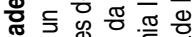
은

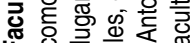
证 ฐ తo

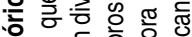

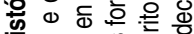
政 \& 즌 $\frac{\pi}{5}$ 응

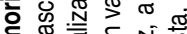

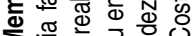
$\sum \frac{\pi}{0} \frac{\omega}{5}$ 更 边 


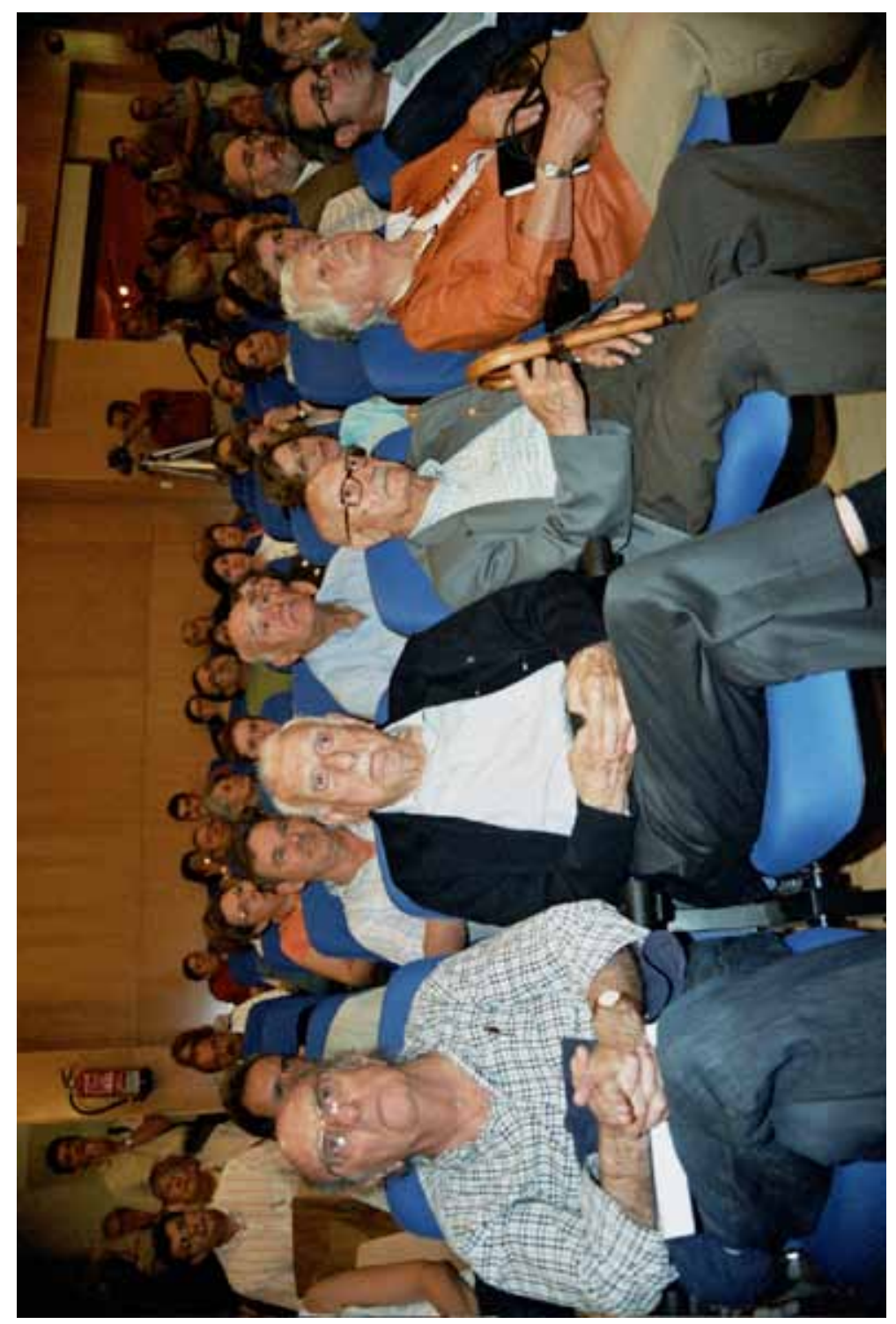
동 ๘

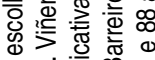

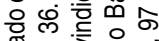
뜽 은

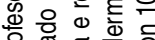

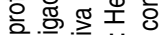

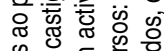

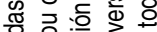

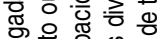
흥 능 용

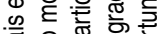

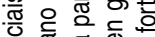

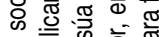

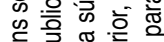

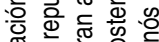
Nㅗㄴ 응 흥 은 쥰 쥰 깅 유 등 भิ 즌 흥 क 징 入 잋 흥흐워ํ 후윤든 음 뜬 뜽흐 응 을 등ㅎㅀ 충

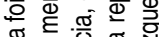

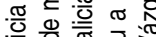

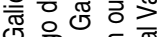
잉잉 쥬 정 즁

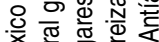
영 흔 으형 즁 헝ㅎㅇ응 잉 응

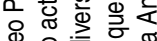

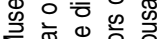

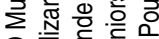
잃 잉 क .ํํ 진 \&

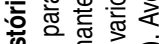
을 둥 뜬 유 $\frac{1}{1}$ 흥 웡 인 흐응 응 특 응 0 응

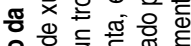

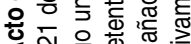
ष

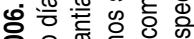

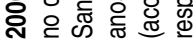




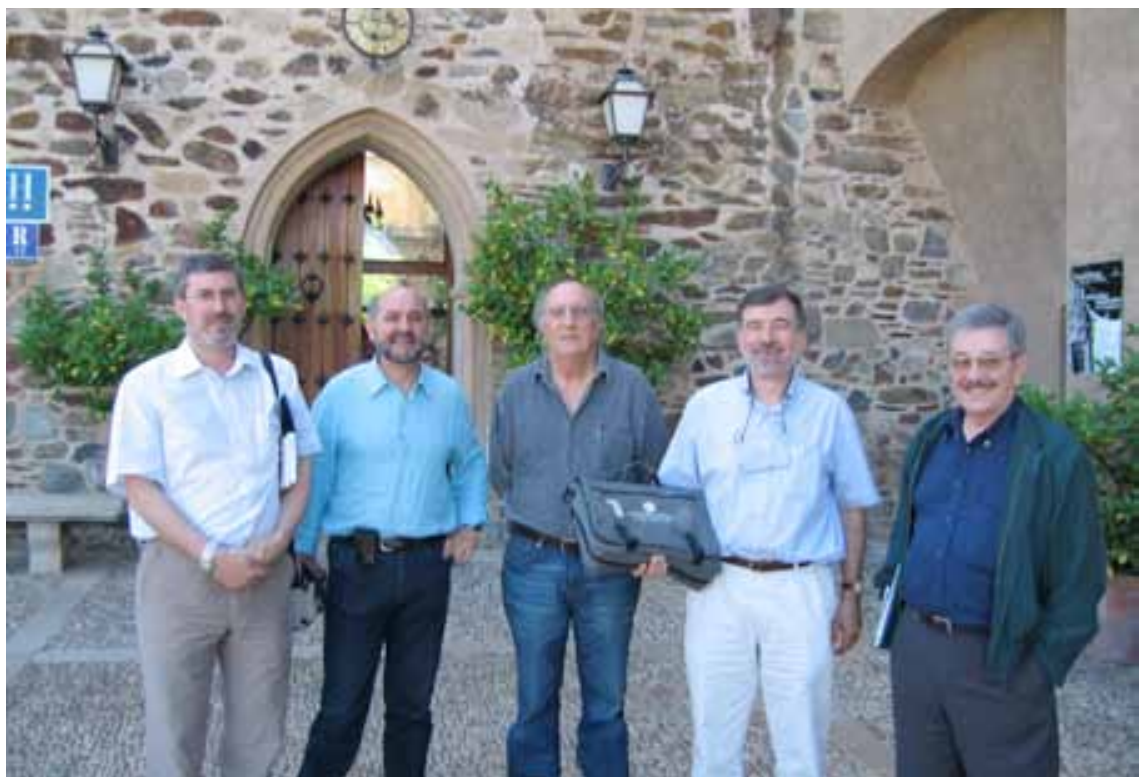

2007. A singradura final. Guadalupe (Cáceres). Ás portas da Hospedería del Real Monasterio, a piques de iniciar a viaxe de retorno a Galicia. Alí tivo lugar o XIV Coloquio de Historia de la Educación, do 25 ao 28 de xuño de 2007. Sería o derradeiro ao que concorrese Herminio. A el levou unha comunicación que tiña por título: "José Castillejo [1877-1945] y el 'Puente hacia Europa': de la creación de la Junta de Ampliación de Estudios al exilio. Pequeña glosa sobre textos de David Castillejo, Irene Claremont y Rafael Martínez Nadal".

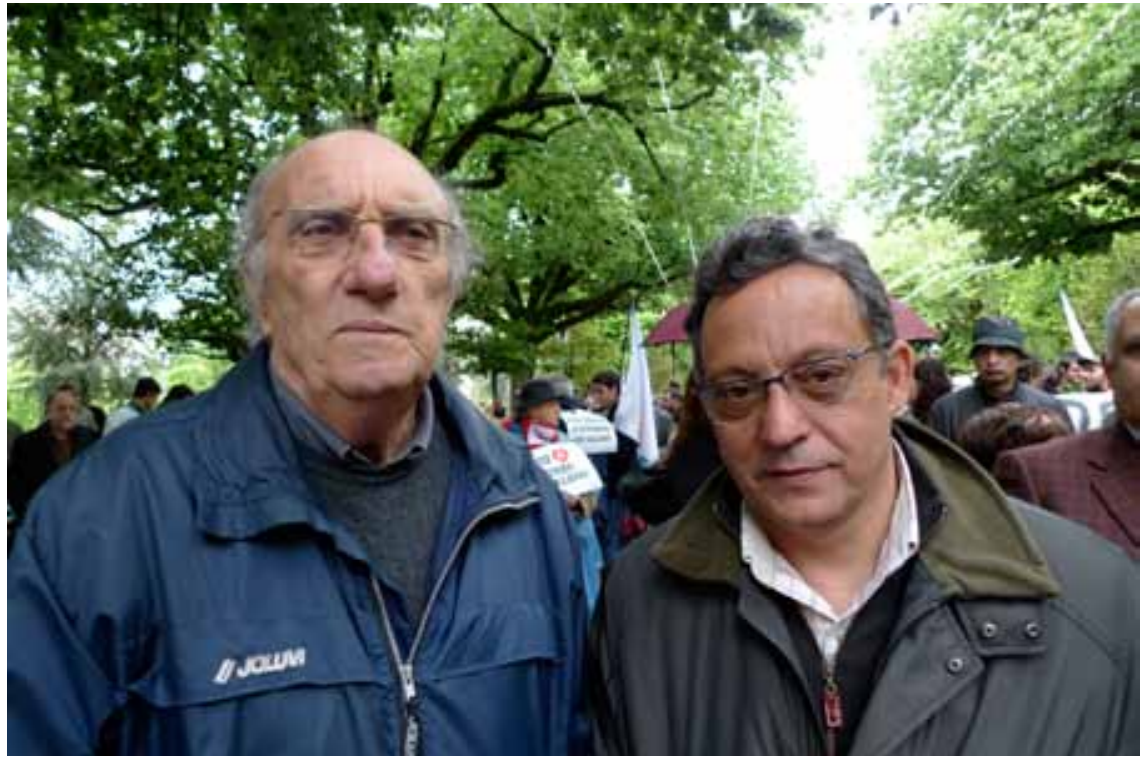

2009. A lingua de nós. Herminio e Narciso na primeira gran manifestación en defensa da lingua galega, celebrada en Santiago de Compostela o 17 de maio de 2009. Cando Herminio recibiu a foto, escribiulle o seguinte ao seu amigo: "¡Estamos igualiños a como somos, compañeiro!... En fin, coido que xa podemos dicir que foi un día histórico. Eso é o máis importante". 


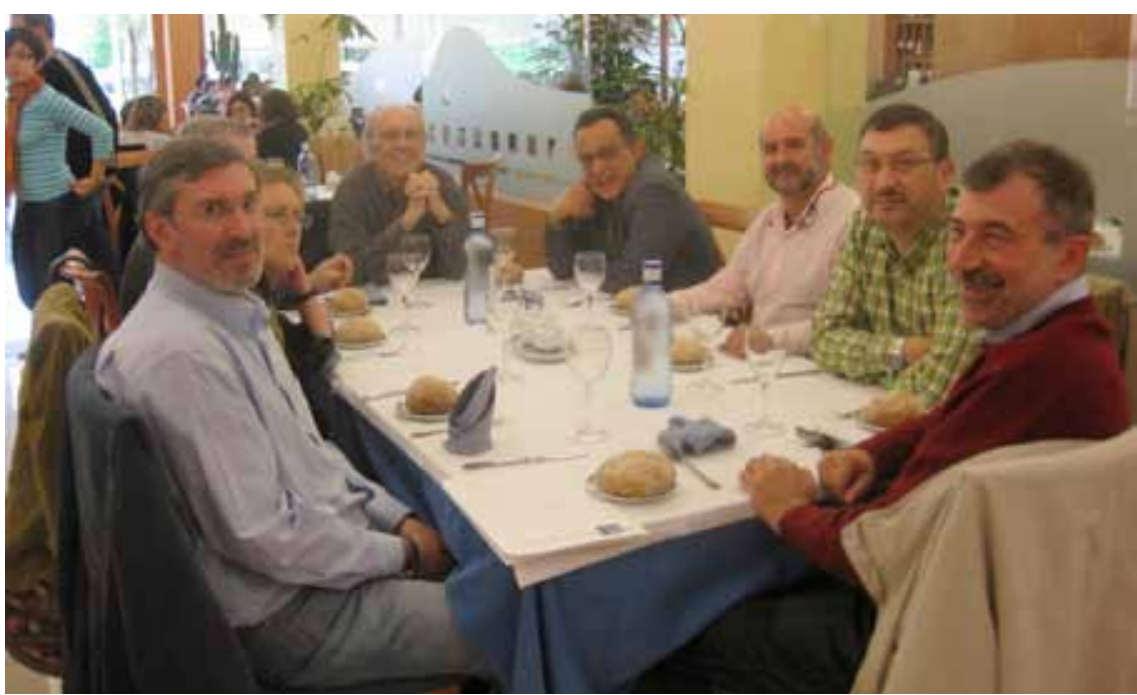

2010. Comensais da irmandade. Cada curso, entre o Nadal e a primavera, reuniámonos o Comité de redacción e o Consello asesor desta nosa revista para analizar a última achega e programar os contidos do número seguinte. Unha xuntanza que sempre comezaba no despacho de Herminio Barreiro, como director da publicación periódica, e remataba nalgunha aula ou seminario da Facultade de Ciencias da Educación de Compostela. Entremedias, non podía faltar un xantar de confraternidade do grupo Sarmiento. No Monte da Condesa, por costume. Ao derradeiro con el corresponde esta imaxe tomada o día 30 de abril de 2010.

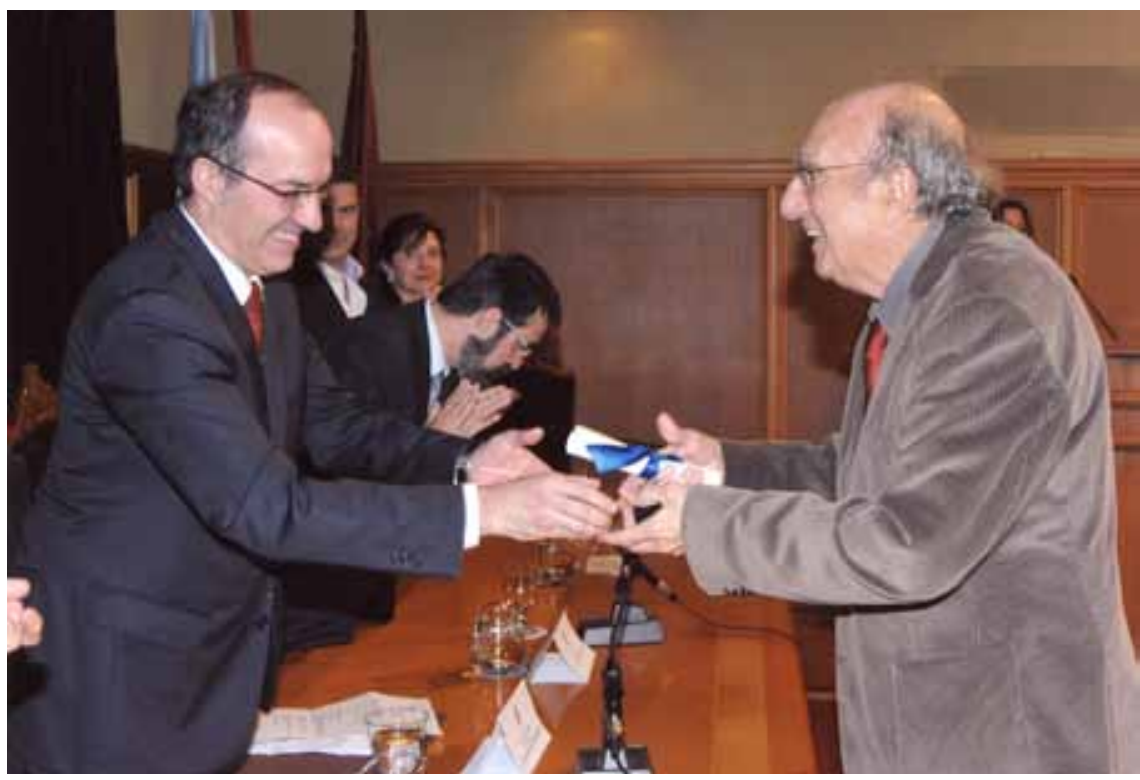

2010. Recoñecemento institucional e condecoración académica. No Salón Nobre do Colexio de Fonseca, o 16 de xuño de 2010, Herminio Barreiro recibía a insignia Fonseca e o correspondente diploma acreditativo de mans do reitor Senén Barro Ameneiro. Acontecía despois de trinta e catro anos de servizos ininterrompidos á Universidade de Santiago de Compostela. No seu caso particular cunha entrega plena, alén dos días e das horas. 


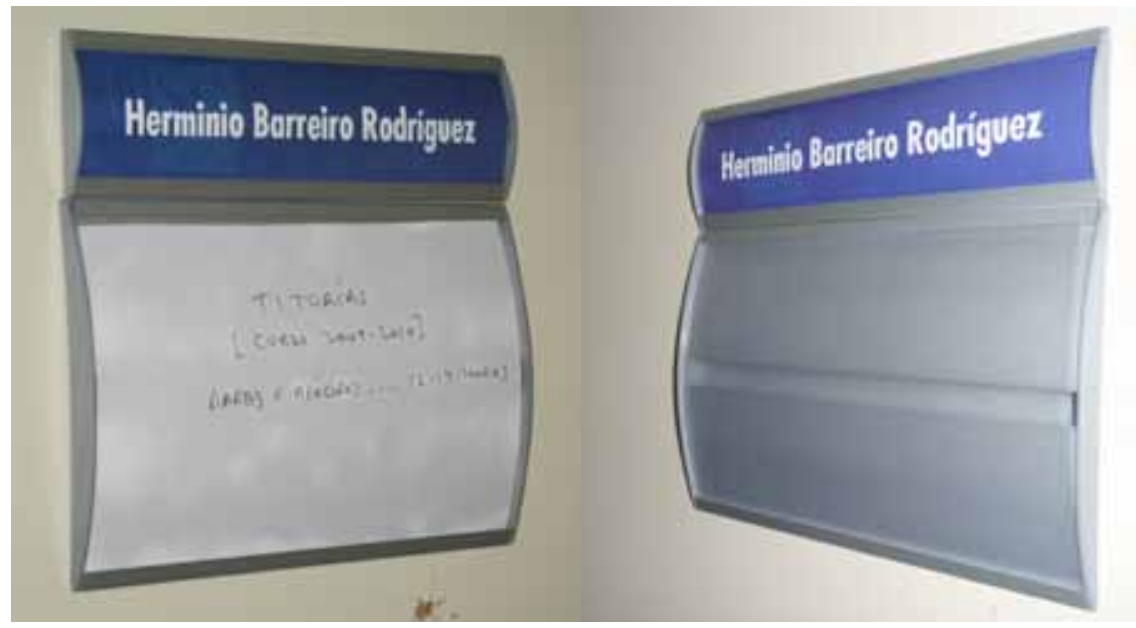

2009-2010. Titorías preceptivas. O seu derradeiro horario formal de atención ao alumnado. Pero unicamente iso. Porque sempre se atopaba á agarda de alguén e decote ao dispor de todas e todos. 2011. Sen el. O despacho orfo. Labor comprido. 